\title{
THE TASMANIAN BLACKBIRD ERADICATION PROGRAMME, 1941-47
}

\author{
by Eric R. Guiler
}

(with three tables)

GUILER, E.R. 1989 (31:x): The Tasmanian blackbird eradication programme, 1941-47. Pap. Proc R. Soc. Tasm. 123: 55-61. https://doi.org/10.26749/rstpp.123.55 ISSN 0080-4703. Department of Zoology, University of Tasmania, GPO Box 252C, Hobart, Australia 7001.

The European blackbird was introduced into Tasmania as early as 1827 ; by 1930 the bird was widely distributed and was becoming a pest to the small fruits industry. A bounty scheme, begun in 1941, resulted in the destruction of 79298 birds and 21848 eggs by 1946, but was ineffectual in eradication because it was too late in being introduced and was ill-conceived biologically. The birds may have contributed to the decline of the small fruits industry.

Key Words: blackbird, Turdus, Tasmania, eradication.

\section{INTRODUCTION}

The European blackbird, Turdus merula, is firmly established as a part of the Tasmanian fauna and is widespread throughout most of the State, being abundant in urban and fruit-growing areas. It is found in native habitats, extending to the West Coast.

The popularly accepted account of the initial introduction is that it was by a criminal act at Beaumaris Zoo, Hobart, on 14 August 1923, when a cage containing a variety of European birds was rifled. The more valuable species were stolen but the 12 blackbirds were allowed to go free, the wire of the roof of the cage being rolled back to facilitate this.

However, there is evidence to show that blackbirds were brought to Tasmania many years before that date. Lawson (1949) recorded that Capt. Langdon brought a shipment of dogs and birds, including blackbirds, from England in 1827. The birds were greeted with joy by the homesick settlers. A pair of blackbirds was brought in by a Mr Muston in 1834 (Ross 1835), the birds arriving in Hobart (Marine Board 1834).

Nothing is known of the fate of these birds or whether they were released into the wild, but the species ultimately became established. It would be hard to find a better environment for their success - abundant food in suburbia, vegetable farms and especially in the small fruit orchards; safe nesting and roosting sites available in the surrounding bush and in blackberry bushes; the winters are relatively mild. The spread of the birds may well have been rapid. It is, however, largely undocumented.

A nest with four eggs was found at Russell Plains near Launceston in December 1916 (Dove 1919). Lord (1919) drew attention to the fact that blackbirds were nesting in Tasmania and exhibited specimens at a Tasmanian Field Naturalists' Club meeting in 1920. The fact that he took the trouble to record their presence would indicate that they were not then very common. No attempt was made to kill or capture wild blackbirds or those which escaped from the Zoo in 1923; although Lord foresaw their danger to fruit-growers and urged the City Council in 1923 to destroy the birds, no action was taken (Guiler 1986). L. Wall (pers. comm.) has documentary evidence of their presence as far away as Port Davey by 1925. The Minutes of the Royal Society of Tasmania recorded, in May 1928 , that blackbirds had been seen in the vicinity of the Hobart Botanical Gardens (Bryden 1966), suggesting that there were still not many in this area.

However, by 1930 there were sufficient blackbirds near Launceston for P. Eastoe of St Leonards to complain to the Fauna Board that they were eating his currants, strawberries and raspberries. He was told to ask the Agriculture Department to destroy them (Animal \& Birds Protection Board (ABPB) 1930a).

In 1930 also, they were introduced to Flinders Island (Green 1969): two years later they were breeding there and built up in such numbers that by 1942 Messrs Goss and Dart lodged bounty claims 
for sorne of them (Pest Account Book). They are now found there in the native ti-tree habitat (Green 1969).

The rapidity of the spread of blackbirds suggests that they may have been released in many places throug hout the State. Dr W. Bryden (pers. comm.) has a strong recollection of Sir William Crowther telling hin that his father liberated blackbirds in paddocks behind Burnie to control pasture pests.

\section{OBSERVATIONS}

The berry fruits industry, with an emphasis upon raspberries, was concentrated in the river valleys, particularly the Huon, D'Entrecasteaux Channel and Upper Derwent Valley districts, although there were also growing regions in the Tamar district and elsewhere in the north of the State. The berry farms were mostly small in size, $0.4-1.6$ ha ( $1-4$ acres), although a few were only 0.3 ha. Only 170 of the 1700 registered fruit farms were larger than 4 ha, while the largest (at Collinsvale) covered 27 ha (Register of Fruit Growers). The smaller holdings would be highly vulnerable to predation by blackbirds which found ready shelter in the adjacent scrub.

Matters relating to the fruit industry initially were the responsibility of the Small Fruits Advisory Committee from 1932-39, before the Stone and Berry Fruits Board (SBFB) was established under an Act of 1939. This Board soon became involved with the blackbird problem.

The Animals and Birds Protection Board (commonly known as the Fauna Board) was charged, among other things, with the protection of native fauna. It had no responsibility towards the eradication of other species, particularly where, as in this case, the Board had played no part in their introduction, although it had peripheral interest in the eradication campaign. Pest control was a function of the Department of Agriculture.

The presence of blackbirds was recognised as a threat to the export small fruit industry and the Government experts hoped, in 1928, to have them exterminated before they became a pest (Bryden 1966). The Fauna Board, which became concerned about the matter in 1929, drew the Government's attention to the existence of a colony of blackbirds, adding that these would become a menace to orchardists and that measures should be taken to exterminate the birds (ABPB 1930b). Some discussions ensued between the Board and the Department of Agriculture, resulting in the Board being led to believe that there was no need for it to do anything as the Government was going to take action.

A bounty scheme was introduced in May 1930 with a payment of 10 shillings per dead blackbird, an unrealistically large sum. By August about 200 birds must have been killed as no less than $£ 100$ had been paid out. Predictably, the scheme was abandoned as too expensive (ABPB 1930c).

The matter was left in the hands of the Department of Agriculture, but little, if anything more was done even when the Small Fruits Advisory Committee was set up in 1932. The Minutes of this Committee do not record any concern for the looming blackbird threat.

It was not until 1940, when the depredations of the blackbirds became more serious, that strong pressure was exerted for Government action to control them. The SBFB received from F. McDermott, M.H.A., a request for a bounty scheme, probably originating from someone else as McDermott was not a fruit-grower (Mr D. Dwyer, former head of the Attorney-General's Department, pers. comm.). The SBFB passed the request to the Department of Agriculture which organised a conference with the Fauna Board, the only concrete result of which action was that the Fauna Board published drawings for widespread display showing both sexes of blackbird and the eggs (ABPB 1940).

In the meantime the SBFB requested that the Government declare blackbirds noxious vermin (SBFB 1940). This would have involved landowners in an obligation to kill the birds if they were found on their properties. No action was taken on this request but, as the birds were always unprotected, they could be killed at any time.

The SBFB requested the Government, in 1941, to provide $£ 500$ as a special grant to fund a bounty scheme whereby sixpence would be paid for each bird's head and twopence for each egg and that it be made an offence for any person to refuse or neglect to eradicate blackbirds on their properties, with a penalty of $£ 2$ (SBFB 1941a). Both requests were agreed to by the Government but, rather significantly, it was noted that some of the community liked having these birds on their properties.

Another decision taken at this time was to offer a prize of 10 guineas for the best suggestion for eradicating the pest (SBFB 1941a) but subsequent Minutes are not clear as to who won the prize or the nature of the suggestions. Fauna Board member P. Wigg was one of the finalists.

The payment arrangements for the bounty were 
the same as those used about 50 years earlier for thylacine bounties (Guiler 1985), the head or (in the case of the birds) the eggs to be produced to a Police Officer or other authorised person, who would issue a certificate to be presented to the Board for payment.

The Fauna Board commented as early as 1941 that the bounty scheme was useless, a statement described as nonsense by the SBFB. The Fauna Board requested in July 1941 that poisons not be used in the campaign (ABPB 1941b) and the SBFB agreed to this.

Other species were accidentally suffering in the campaign; general concern was expressed by the Tasmanian Field Naturalists' Club, specifically fearing that the eggs of the native thrush would be mistaken for those of the blackbird; colour drawings of the olive-green thrush and the blue blackbird eggs were therefore circulated (SBFB 1941c).

The Police Department, which handled most of the bounty claims, was tired of the whole business and the work involved, and recommended to the Fauna Board in 1942 that the bounty on eggs be discontinued as it encouraged disturbance of the nests of other species. The Department also suggested that, if the scheme were continued, the payment should be for the whole nest and not for the eggs (ABPB 1942). Nothing came of these proposals, but it may be significant that the request was made to the Fauna Board.

There appears to have been some niggling between the two Boards, perhaps started by the Fauna Board's comment on the validity of the scheme. The Minutes of both Boards show points of disagreement and this became evident when the SBFB, in 1942, requested the Government to give them representation on the Fauna Board (SBFB 1942a). The Minister promised to do this "whenever the opportunity presented itself" (SBFB 1943a). However, this never came to pass, partly because Fauna Board member P. Wigg was a fruitgrower and so could be said to represent their interests.

Fauna Board representatives attended a meeting of the SBFB on 4 November 1942 and formally requested the termination of the bounty scheme. One of these representatives, Dr Pearson, did not endear himself to growers by saying that the scheme as constituted was useless and that they should concentrate their efforts on killing the female blackbirds. The Fauna Board pressed the views of the Police Department that disturbance was being caused to the nests of other species (SBFB 1942b). The scheme continued, although an attempl was made to alter it by eliminating the egg bounty and replacing it with a reward of one shilling per adult bird and sixpence per fledgling, the reward to be paid only for birds from fruitgrowing areas. These suggestions raised a storm of protest from the Municipalities and they were dropped (SBFB1943).

Although the scheme continued in 1944, the issue appeared less frequently in the Minutes of the SBFB and perhaps the bounty's most devoted advocates were beginning to feel that the results, although substantial, were not having much effect on blackbird numbers. The Minister for Agriculture visited the SBFB Meeting in May 1945 and said that he would place the request for the bounty money before Cabinet. This was unusual, as recurring expenditure is a departmental item which would not necessarily go to Cabinet for individual approval; it may imply that Cabinet or some members of it were objecting to allocating $£ 500$ per annum to a scheme of dubious value. The scheme continued until the 1946-47 Estimates, when the amount requested was reduced from $£ 500$ to $£ 250$. This was considered adequate to meet claims up to June 1947 and the SBFB was informed that no increase in this sum could be expected in the 1947-48 Budget (SBFB 1947a). (The Minutes of the Board from 1947 were not available.)

The number of birds and eggs destroyed is substantial and represents a lot of hunting effort (table 1). The breeding cycle of the blackbird coincides with the financial year (table 2) so that biologically valid data are available. The figures in table 1 differ from the annual totals in table 2 , but no explanation can be offered for this, the material being given as in the sources.

More eggs than birds were destroyed in October, except in 1943-44, but the combined totals of birds and eggs destroyed were greatest in December and January. The season in 1945 may have been later than in other years, as the claims were not lodged in numbers until a month later than usual and continued at a high level for an additional month. The number of birds killed in 1944-45 shows a bimodality which is absent from all other years. The annual differences may be due to weather, economic conditions or wartime labour problems, apart from any biological factors which may be involved.

The large number of eggs submitted in December each year probably is the result of a second breeding as the first laying occurs two months or so earlier than this. 1 do not believe that the eggs were stockpiled, as the total number of eggs per claim 
TABLE 1

Heads and Eggs of Blackbirds upon which Bounty was paid

\begin{tabular}{lcccccc}
\hline Financial year & Birds & Eggs & Total & \multicolumn{3}{c}{ Cost } \\
& & & & s & d \\
\hline $1941-42$ & 19380 & 8709 & 28089 & 557 & 1 & 6 \\
$1942-43$ & 18652 & 4457 & 23109 & 503 & 8 & 10 \\
$1943-44$ & 16049 & 3531 & 19580 & 430 & 13 & 0 \\
$1944-45$ & 12984 & 2360 & 15344 & 344 & 5 & 4 \\
$1945-46$ & 12233 & 2791 & 15024 & 328 & 9 & 8 \\
Totals & 79298 & 21848 & 101246 & 2163 & 18 & 4 \\
\hline
\end{tabular}

Source: Minutes SBFB, 18 August 1946.

TABLE 2

Blackbirds and Eggs presented each Month for Bounty in Tasmania (1941-45)*

\begin{tabular}{|c|c|c|c|c|c|c|c|c|}
\hline \multirow[b]{3}{*}{ Month } & \multicolumn{8}{|c|}{ Financial year } \\
\hline & \multicolumn{2}{|c|}{$1941-42$} & \multicolumn{2}{|c|}{$1942-43$} & \multicolumn{2}{|c|}{$1943-44$} & \multicolumn{2}{|c|}{$1944-45$} \\
\hline & Birds & Eggs & Birds & Eggs & Birds & Eggs & Birds & Eggs \\
\hline Jun & 375 & 18 & 251 & 19 & 649 & 17 & 498 & 8 \\
\hline Jul & 166 & 0 & 161 & 5 & 210 & 3 & 241 & 11 \\
\hline Aug & 128 & 0 & 121 & 22 & 143 & 0 & 150 & 11 \\
\hline Sep & 200 & 49 & 58 & 31 & 212 & 28 & 97 & 31 \\
\hline Oct & 1197 & 1946 & 738 & 1045 & 474 & 391 & 166 & 227 \\
\hline Nov & 2479 & 2443 & 1438 & 936 & 1325 & 1314 & 1111 & 733 \\
\hline Dec & 5221 & 2868 & 5217 & 1474 & 3374 & 1074 & 1320 & 467 \\
\hline Jan & 5896 & 916 & 3629 & 476 & 3668 & 396 & 3567 & 488 \\
\hline Feb & 2151 & 285 & 4446 & 461 & 2714 & 143 & 1639 & 131 \\
\hline Mar & 1184 & 123 & 1504 & 124 & 1638 & 102 & 2400 & 155 \\
\hline Apr & 232 & 12 & 685 & 49 & 843 & 114 & 1120 & 37 \\
\hline May & 277 & 33 & 309 & 20 & 730 & 43 & na & na \\
\hline Annual totals & 19506 & 8693 & 18611 & 4662 & 15980 & 3625 & 12309 & 2299 \\
\hline Totals & \multicolumn{8}{|c|}{66406 birds, 19279 eggs } \\
\hline
\end{tabular}

Source: Pest Account Cash Book, SBFB.

* Numbers obtained by conversion from amounts paid for each category. na $=$ not available. 
TABLE 3

Average Number of Birds and Eggs per Claimant during the Tasmanian Blackbird Bounty (1941-45)

\begin{tabular}{|c|c|c|c|c|c|c|c|c|}
\hline \multirow[b]{3}{*}{ Month } & \multicolumn{8}{|c|}{ Financial year } \\
\hline & \multicolumn{2}{|c|}{$1941-42$} & \multicolumn{2}{|c|}{$1942-43$} & \multicolumn{2}{|c|}{$1943-44$} & \multicolumn{2}{|c|}{$1944-45$} \\
\hline & Birds & Eggs & Birds & Eggs & Birds & Eggs & Birds & Eggs \\
\hline Jun & 20.8 & 9.0 & 14.8 & 9.5 & 16.2 & 4.2 & 24.9 & 4.0 \\
\hline Jul & 6.9 & 0 & 10.7 & 2.5 & 13.1 & 3.0 & 26.8 & 2.0 \\
\hline Aug & 7.1 & 0 & 15.1 & 7.3 & 11.0 & 0 & 16.7 & 11.0 \\
\hline Sep & 8.0 & 9.8 & 6.4 & 7.7 & 11.2 & 5.6 & 13.9 & 15.5 \\
\hline Oct & 5.0 & 11.1 & 5.2 & 16.9 & 8.5 & 13.0 & 6.9 & 14.0 \\
\hline Nov & 6.5 & 9.6 & 6.6 & 7.7 & 8.0 & 11.0 & 11.6 & 10.3 \\
\hline Dec & 8.7 & 8.6 & 11.0 & 16.5 & 13.0 & 8.4 & 15.0 & 12.3 \\
\hline Jan & 11.0 & 5.3 & 13.6 & 40.6 & 20.0 & 9.4 & 24.9 & 10.2 \\
\hline Feb & 13.2 & 6.6 & 2.0 & 51.8 & 25.0 & 6.2 & 23.0 & 6.6 \\
\hline Mar & 13.3 & 8.2 & 1.5 & 8.2 & 19.3 & 8.5 & 36.4 & 9.1 \\
\hline Apr & 10.5 & 1.7 & 12.0 & 3.5 & 14.1 & 9.5 & 36.1 & 6.2 \\
\hline May & 9.9 & 8.2 & 12.4 & 3.3 & 21.5 & 7.1 & na & na \\
\hline Annual average & 10.07 & 7.81 & 9.28 & 14.56 & 15.1 & 7.16 & 21.44 & 9.21 \\
\hline
\end{tabular}

na $=$ not available.

does not support this view. It is more likely that they represent an effort at control being exerted as the fruit ripened.

\section{DISCUSSION}

Little is known of the population dynamics of the blackbird in Tasmania, although some comparisons can be made with English studies (Snow 1958, Lack 1966). Three to five eggs are laid per clutch and the birds usually raise two clutches per annum, with three being frequent. About $90 \%$ of the eggs hatch. Older parents are more successful than firstyear birds and raise 6.3 young to the fledgling stage each year. The survival of the fledglings varies considerably in different habitats, as well as with the maturity of the parents and the seasonal conditions, but about $55 \%$ of them survive to independence and, of these, $16 \%$ successfully overwinter, i.e. about six out of every 100 fledglings. Once adult, they become subject to a $44 \%$ annual mortality rate which is the same for both sexes.

It is likely that the abundant food supply, milder winters and better Tasmanian conditions result in lower mortalities and better breeding rates, aided by the longer warm seasons. This means that more young birds must be killed to reduce future populations.

The data presented in table 2 suggest that a small number of birds may have bred all year around, although some of the eggs could have been collected outside the breeding season from longabandoned nests.

Egg removal may have some effect upon the production of young, table 2 showing a substantial decline in the number of eggs taken from 1941 to 1947. However, it is more likely that this is a result of a decline in hundting interest, as the catch per unit of effort (table 3) shows an increase over the same period, indicating that little, if any, effect was being felt by the bird population.

Both birds and eggs were taken in an unorganised fashion in both rural and urban areas, irrespective of whether fruit was grown there or not. J. Napier (pers. comm.) told me that as a small boy he made pocket money from this source in the St Marys district, which is many kilometres from any fruitgrowing areas.

Two annual competitions were held, in 1941 and 
1942, with prizes for the largest number of eggs and birds caught by an individual. The largest number of birds were caught in orcharding areas at Nichols Rivulet (247) and Castle Forbes Bay (190) but most eggs were taken in both years by New Town residents (356 and 140) (SBFB 1943b).

The general impression is that too many claims were paid on birds from non-fruit-growing areas and that many of the birds killed would have died of natural causes later in the season.

There is no point in anaylsing the bounty data to assess the relative density of blackbirds in different parts of the State. The Pest Petty Cash Book showed that of the first 200 entries only 24 bounty receipts could be traced to their home address. These recipients killed 63 birds and took 69 eggs, whereas totals for the first 200 claims were 595 and 1081 respectively. It is believed that many of the claimants were small boys whose names would not appear in the usual sources such as Postal Directories. No valid conclusions could be based on such incomplete evidence.

Almost all the claims were for small numbers of birds or eggs, only $50 \%$ reaching double figures. This was adminstratively expensive and troublesome. Clearly there was no stockpiling of materials, which supports the theory that small boys formed the main part of the collecting force. It also suggests very strongly that there was no systematic approach towards the eradication of the pest in places where it was most harmful.

\section{CAUSES OF FAILURE OF THE CAMPAIGN}

Early literature tells us little of the pre-1930 distribution of blackbirds but it can be assumed that they spread from Hobart, probably from Launceston and possibly from other nuclei. In all instances humans were the method of establishment of the birds.

The primary cause of failure to eradicate or even partially control the blackbirds was that the killing commenced far too late after the problem became obvious. Had the warnings of Lord in 1919 and 1923 been heeded, or even the Fauna Board concern in 1930, there might have been some chance of control being gained, but by 1941 the birds were too widespread and numerous.

Once the birds became established, their melodious singing developed an affection for them in many people, so that any campaign for their eradication was foredoomed because of an absence of total community involvement or support.

To save costs, the bounty should have been aimed at one sex or the other; this was realised by the Fauna Board in their 1942 proposals which were rejected. It is usual to target the female but, in this instance, it probably would have been better to have selected the male, who is more conspicuous and, with his flamboyant breeding and territorial behaviour, would have presented better shooting. Since both parents are involved in rearing the young it makes little difference which one is absent.The robbing of nests was of little value as the female would begin laying a new clutch soon afterwards.

The methods of killing the birds were restricted by the banning of poisons and by wartime shortages of .22 calibre ammunition. The SBFB frequently requested the Munitions Board to release more supplies but to no avail.

Most of the bounties were paid in the interval October to March each season. This may have been because the birds were more conspicuous during the breeding season or because the fledgling young provide easy targets and can even be knocked down with sticks. The killing months also represent the concern of the grower for his developing crop and the need to protect it. The campaign would have been more effective had the breeding stock been reduced by a vigorous winter operation, particularly in the fruit-growing areas, with an increased bounty during that time.

The purpose of the bounty scheme was to relieve fruit-growers of the blackbird pest but the attempt to control the birds over the whole of the State did not achieve worthwhile results. The campaign was ill-conceived both biologically and administratively. There was little hope of eradicating blackbirds, but a touch of realism would have shown that more direction was needed than merely the setting up of such a scheme.

Economic factors and changing conditions after the war brought about a decline in the small fruits industry. The SBFB predicted that if the bounties were discontinued, it would be the end of the industry (SBFB 1947b). This prediction may have been an overstatement but there can be little doubt that the blackbirds did play a part in the industry's decline.

\section{SOURCES}

The sources used in preparing this were the Minutes of the Stone and Berry Fruits Board (SBFB); Pest Account Book of that Board, June 1941-April 1945; Minutes, Small Fruits Advisory Committee, 1932-36; Minutes, Animals and Birds 
Protection Board 1928-47 (ABPB); Register of Fruit Growers. All of these are held in the State Archives of Tasmania.

\section{ACKNOWLEDGMENTS}

I am indebted to Mr L. Wall, Dr W. Bryden and Mr J. Napier for literature references and personal reminiscences.

\section{REFERENCES}

Animal \& Birds Protection Buakt (ADPB) Minutes, 1930a: 2 Nov.; 1930b: 4 Apr., 6 May, 26 Aug.; 1930c: 17 May; 1931: 5 May; 1940: 2 Apr., 7 May; 1941a: 3 May; 1941b: 7 May; 1942: 27 Jul.

Bryden, W., 1966: Tasmanian Museum and Art Gallery: Historical note. Pap. Proc. R. Soc. Tasm. 100: 21-26.

Dove, H.S., 1919: The blackbird in Tasmania. Emu 19:70.

Green, R.H., 1969: Birds of Flinders Island. Rec. $Q$ Vict. Mus, 34: 1-32.

GuILER, E.R., 1985: THYLACINE - THE TRAGEDY OF THE TASMANIAN TIGER. Oxford University Press, Melbourne.

Guller, E.R., 1986: The Beaumaris Zoo in Hobart. Pap
Proc. Tasm. Hist Res. Assoc. 33(4): 21-27.

LACK, D., 1966: The European Blackbird in gardens and woods. BIRD POPULATION STUDIES. Oxford University Press, London.

LAWSON, W., 1949: BLUE GUM CLIPPERS AND WHALE SHIPS OF TASMANIA. D \& L Books, Launceston.

Lord, C.E., 1919: Proceedings Meeting, 10 Nov. Pap. Proc. R. SOC. Tasm. (1920): 155.

MARINE BOARD, 1834: Shipping arrivals in Hobart. State Archives of Tasmania, MB/2/39: 197.

Pest Account Petry Cash Book, undated. State Archives of Tasmania, CB $36 / 9$.

Register of Small Fruit Growers, undated. State Archives of Tasmania, CB 36(4).

Ross, J., 1835: Chronological view of events in Van Diemen's Land in 1835. TASMANIAN ALMANACK. J. Ross, Hobart Town.

Small Fruits Advisory Committee, 1932-36: Minutes. State Archives of Tasmania, CB 36.

SNow, D.W., 1958: A STUDY OF BLACKBIRDS. Allen \& Unwin, London.

Stone \& Berry Fruits Board (SBFB) Minutes, 1940: 15 Nov., 17 Dec.; 1941a: 17 Jan.; 1941b: 9 Sept.; 1941c: 14 Oct.; 1941d: Nov.; 1942a: 25 Sept.; 1942b: 14 Nov.; 1943a: 7 Jan.; 1943b: 13 Apr.; 1947a: 20 Nov,; 1947b: 28 Mar.

(accepted 12 May 1989) 